\title{
FUNCTIONS OF PATENTS
}

\author{
DESI RATNA SARI \\ 155100016 \\ Fakultas Komputer \\ 4487571-85 \\ desiratnasarii.student@umitra.ac.id
}

\begin{abstract}
So far, we've seen that patents grant inventors ownership of their original ideas, giving them temporary control over who can use those ideas. This system shows up in some form or another in most all developed nations, because it is so important to a country's development. Patents affect society in a number of a ways, but at their core, they serve a very basic function: They help encourage the advancement of science and technology.
\end{abstract}

Keyword : Functions Of Patents 


\section{A. INTRODUCTION}

\section{Patent :}

A patent is a form of intellectual property. A patent gives its owner the right to exclude others from making, using, selling, and importing an invention for a limited period of time, usually twenty years. The patent rights are granted in exchange for an enabling public disclosure of the invention. People who are employed to do research are often obligated by their employment contracts to assign inventions to their employer. In most countries patent rights fall under civil law and the patent holder needs to sue someone infringing the patent in order to enforce their rights. In some industries patents are an essential form of competitive advantage; in others they are irrelevant.

The procedure for granting patents, requirements placed on the patentee, and the extent of the exclusive rights vary widely between countries according to national laws and international agreements. Typically, however, a granted patent application must include one or more claims that define the invention. A patent may include many claims, each of which defines a specific property right. These claims must meet relevant patentability requirements, such as novelty, usefulness, and non-obviousness.

Under the World Trade Organization's (WTO) TRIPS Agreement, patents should be available in WTO member states for any invention, in all fields of technology, provided they are new, involve an inventive step, and are capable of industrial application. ${ }^{[4]}$ Nevertheless, there are variations on what is patentable subject matter from country to country, also among WTO member states. TRIPS also provides that the term of protection available should be a minimum of twenty years 


\section{Functionts}

So far, we've seen that patents grant inventors ownership of their original ideas, giving them temporary control over who can use those ideas. This system shows up in some form or another in most all developed nations, because it is so important to a country's development. Patents affect society in a number of a ways, but at their core, they serve a very basic function: They help encourage the advancement of science and technology.

- Patents do this in two major ways:

They give inventors an opportunity to profit from their creations. The process of inventing a new device or process is an extremely difficult one, and few people would go through it if there weren't any financial reward.

- They help disseminate technological information to other inventors. When you apply for a patent, you are required to submit a detailed description of your invention. This description becomes part of the patent office's database, which is public record. Once the patent has expired, the idea is more readily available than it would have been if it had never been patented.

Patents motivate individual inventors, but they also motivate large companies. They are particularly important to chemical, computer-technology and pharmaceutical firms. In these markets, your success might be wholly dependent on having exclusive rights to innovative products. Intellectual property makes up a huge chunk of these companies' assets. Currently, IBM leads the pack in the invention race, boasting more than 2,000 patents in 1999 and again in 2000.

When something is invented as part of a person's work for a company, the company is typically given control over the invention, though the patent may officially go to the individual inventor. This arrangement varies depending on 
the country and the nature of the employee's contract. If you are contracted to grant your employer all patent rights to your work, selling your own invention would actually be infringing your own patent (and your employer could take you to court). The same holds for copyrighted "work-for-hire." You may be the original creator, but if you republish the work yourself, you are infringing the copyright.

In the next section, we'll find out how an inventor actually goes about patenting an idea. As we'll see, this is usually a long, expensive and difficult process

\section{B. CONCLUSION}

Patents motivate individual inventors, but they also motivate large companies. They are particularly important to chemical, computer-technology and pharmaceutical firms. In these markets, your success might be wholly dependent on having exclusive rights to innovative products. Intellectual property makes up a huge chunk of these companies' assets. Currently, IBM leads the pack in the invention race, boasting more than 2,000 patents in 1999 and again in 2000.

\section{ACKNOWLEDGEMENT University Of Indonesia University Of Mitra Indonesia Telkom University University Of Mellbourne Saitama University}




\section{REFERENCE (Based ISO 690)}

[1] A. S. Putra And O. M. Febriani, "Knowledge Management Online Application In Pdam Lampung Province," In Prosiding International Conference On Information Technology And Business (Icitb), 2018, Pp. 181-187.

[2] A. S. Putra, O. M. Febriani, And B. Bachry, "Implementasi Genetic Fuzzy System Untuk Mengidentifikasi Hasil Curian Kendaraan Bermotor Di Polda Lampung," J. Sist. Inf. Dan Manaj. Basis Data, Vol. 1, No. 1, Pp. 21-30, 2018.

[3] O. M. Febriani And A. S. Putra, "Sistem Informasi Monitoring Inventori Barang Pada Balai Riset Standardisasi Industri Bandar Lampung," J. Inform., Vol. 13, No. 1, Pp. 90-98, 2014.

[4] Putra, Arie Setya. "2018 Artikel Struktur Data, Audit Dan Jaringan Komputer." (2018).

[5] Putra, A. S. (2018, July 17). Paperplain Fundamental Create Application With Borland Delphi 7.0 University Of Mitra Indonesia. Retrieved From Osf.Io/Pbrn9. 


\section{QUIZ Selected Section Class}

\section{E. REFERENCE (Based APA)}

Putra, A. S., Aryanti, D. R., \& Hartati, I. (2018, November). Metode SAW (Simple Additive Weighting) sebagai Sistem Pendukung Keputusan Guru Berprestasi (Studi Kasus: SMK Global Surya). In Prosiding Seminar Nasional Darmajaya (Vol. 1, No. 1, pp. 85-97).

Sari, D. P., Febriani, O. M., \& Putra, A. S. (2018, November). Perancangan Sistem Informasi SDM Berprestasi pada SD Global Surya. In Prosiding Seminar Nasional Darmajaya (Vol. 1, No. 1, pp. 289-294).

Putra, A. S. (2018). Paperplain: Execution Fundamental Create Application With Borland Delphi 7.0 University Of Mitra Indonesia.

Putra, A. S., Sukri, H., \& Zuhri, K. Sistem Monitoring Realtime Jaringan Irigasi Desa (JIDES) Dengan Konsep Jaringan Sensor Nirkabel. IJEIS (Indonesian Journal of Electronics and Instrumentation Systems), 8(2), 221232.

Darmawan, A., Yuliawati, D., Marcella, O., \& Firmandala, R. (2016). Sistem Absensi dan Pelaporan Berbasis Fingerprint dan SMS Gateway. EXPLORE, 7(1).

Febriani, O. M., Wahyuni, T., \& Yusuf, S. (2017). DESIGN OF WEBSITE-BASED INFORMATION SYSTEM FOR EDOCUMENT ADMINISTRASI IN THE COMMUNITY SERVICE UNIT (A Case Study at Rajabasa District).
INTERNATIONAL JOURNAL OF COMPUTERS \& TECHNOLOGY, 16(7), 7010-7020.

Febriani, O. M., \& Wahyuni, T. (2017, October). PERANCANGAN SISTEM E-DOCUMENT ADMINISTRASI LOGBOOK PENELITIAN PADA UNIT LAYANAN DI BANDAR LAMPUNG. In Prosiding Seminar Nasional Darmajaya (Vol. 1, No. 1, pp. 187-194).

Febriani, O. M., \& Permadi, A. B. (2017). Implementasi Sistem Aplikasi Data Bimbingan dan Pelanggaran Siswa pada Sekolah Menengah Atas di Lampung Tengah dengan Metode Analisis dan Desain Sistem Terdistribusi (SSAD). EXPERT, 7(1).

Febriani, O. M., \& Ambarwati, L. (2015). PERANCANGAN APLIKASI PENGOLAHAN DATA PENJUALAN UKM KELANTING KHAS TELO DESA SIDOHARJO KECAMATAN JATI AGUNG KABUPATEN LAMPUNG SELATAN. Jurnal Teknologi Informasi dan Bisnis Pengabdian Masyarakat Darmajaya, 1(1), 77-95.

Febriani, O. M. (2015). Rancang Bangun Aplikasi Ecommercemenggunakan Freewebstore pada UKM Kelanting di Desa Sidoharjo Lampung Selatan. Prosiding Sembistek 2014, 1(02), 446-458. 